\title{
Interaction of Intraleukocytic Bacteria and Antibiotics
}

\author{
Gerald L. Mandell \\ From the Division of Infectious Diseases, Department of Internal Medicine, \\ University of Virginia School of Medicine, Charlottesville, Virginia 22901
}

A в S T R A C T Bacteria that survive inside polymorphonuclear neutrophils (PMN) following phagocytosis are protected from the bactericidal action of most antibiotics. Two possible explanations are altered metabolism by intraleukocytic bacteria or failure of antibiotics to enter the phagosome. The oxygen consumption of intraleukocytic and extraleukocytic bacteria was measured as an index of bacterial metabolism. PMN respiration and bactericidal activity were suppressed with large doses of hydrocortisone and extraleukocytic bacterial oxygen consumption was abolished by the addition of lysostaphin. Intraleukocytic bacterial continued to consume oxygen suggesting that surviving ingested microorganisms are metabolically active. Neither penicillin (which cannot kill intraleukocytic bacteria) nor rifampin (which can kill intraleukocytic bacteria) was bactericidal for staphylococci at $5^{\circ} \mathrm{C}$. Thus, rifampin is not uniquely able to kill "resting" bacteria.

Intraleukocytic or extraleukocytic Staphylococcus aureus were incubated with $\left[\right.$ benzyl $\left.-{ }^{14} \mathrm{C}\right]$ penicillin for $2 \mathrm{~h}$ at $37^{\circ} \mathrm{C}$. Live intraleukocytic bacteria bound only $13 \%$ as much penicillin as live bacteria incubated with killed PMN. To measure the penetration of antibiotics into PMN, $\left[{ }^{14} \mathrm{C}\right]$ rifampin and $\left[{ }^{14} \mathrm{C}\right]$ penicillin were measured in leukocyte pellets and in the supernatant fluid. The total water space in the pellets was quantitated using tritium water and the extracellular water space was measured using $\mathrm{Na}^{2}{ }^{35} \mathrm{SO}_{4}$. All penicillin associated with the cell pellet could be accounted for in extracellular water. Thus penicillin was completely excluded from the leukocytes. Rifampin was concentrated in the cell pellet 2.2 times when compared with the supernatant concentration.

These studies suggest that a likely explanation for the survival of phagocytized bacteria in the presence of high concentrations of most antibiotics is the inability of the

Dr. Mandell is the holder of a Research Career Development Award GM-49520 from the National Institute of General Medical Sciences.

Received for publication 9 January 1973 and in revised form 8 March 1973. antibiotic to enter the phagocyte. Rifampin, which is highly lipid soluble, can enter leukocytes and kill intracellular bacteria.

\section{INTRODUCTION}

Several investigators have demonstrated that bacteria surviving intracellularly within phagocytes are not killed when incubated with concentrations of antibiotics many hundreds of times above the minimum bactericidal concentration (1-6). Intraleukocytic bacteria may be unaffected by antibiotics because $(a)$ the antibiotics do not reach the bacteria in their intracellular location or $(b)$ the antibiotics do reach the bacteria, but because of altered metabolism, the bacteria are insensitive to the lethal action of the antibiotics.

If bacteria that had been ingested by leukocytes were "resting" this could explain their insusceptibility to most antibiotics (7). To test one aspect of this question we studied the bactericidal activity of penicillin (a representative bactericidal antibiotic that does not kill intraphagocytic organisms) and rifampin (the only antibiotic, to date, shown to rapidly kill intraphagocytic organisms) on staphylococci at $5^{\circ} \mathrm{C}$ to see if the antibiotics were effective against these metabolically slowed bacteria. In other experiments the rate of oxygen consumption by both intraleukocytic and extraleukocytic bacteria was measured as an index of the metabolic state of the intraleukocytic bacteria. Leukocyte oxygen consumption was suppressed with hydrocortisone and extraleukocytic bacteria were killed with lysostaphin.

Prior studies in other laboratories suggested that penicillin can penetrate mammalian cells (8). Since bacteria that are killed by penicillin tightly bind this anti. biotic $(9,10)$, experiments were performed to see if intraleukocytic bacteria bind penicillin to the same degree as do extraleukocytic bacteria. In other experiments radiolabeled penicillin and rifampin were incubated with leukocyte suspensions to quantitate the distribution of the antibiotics in the cell pellet. Corrections were made for total water in the pellet measured by tritium water 
(11) and extracellular water in the pellet measured with $\mathrm{Na}^{2}{ }^{36} \mathrm{SO}_{4}(12,13)$.

Penetration of leukocyte membranes by an antibiotic involves passage from an aqueous phase (the extracellular fluid) through a lipid phase (the cell membranes) into an aqueous phase (the phagosome). An aqueouslipid-aqueous phase diffusion model was set up to test the ability of 18 antibiotics to pass through these phases and then kill bacteria.

\section{METHODS}

Oxygen consumption of intraleukocytic and extraleukocytic bacteria. Leukocytes were separated from peripheral blood by dextran sedimentation of erythrocytes. The erythrocytes remaining in the supernatant fluid with the leukocytes were lysed with iced distilled water $\times 2$ (14). 2-4 $\times 10^{7}$ leukocytes (75-85\% polymorphonuclear neutrophils [PMN] ${ }^{1}$ ) in $2.8 \mathrm{ml}$ of Hanks' balanced salt solution (HBSS) with $10 \%$ autologous serum were placed in the chambers of a polarographic oxygen monitor (Yellow Springs Instrument Co., Yellow Springs, Ohio, Model 53). $3 \times 10^{\circ}$ live or heat-killed $S$. aureus $(502 \mathrm{~A})$ were then added to the chamber and oxygen consumption was charted on the recorder of a Gilford 2400 spectrophotometer (Gilford Instrument Laboratories, Inc., Oberlin, Ohio) for $15 \mathrm{~min}$.

In order to eliminate leukocyte oxygen consumption, 4.8 $\mathrm{mg} / \mathrm{ml}$ of hydrocortisone 21-succinate was added after phagocytosis had taken place (15). Extracellular staphylococci were killed by the addition of lysostaphin in a final concentration of $30 \mathrm{U} / \mathrm{ml}$. After the inactivation of lysostaphin with trypsin $(25 \mathrm{mg} / \mathrm{ml})$, viable bacteria were enumerated by hypotonic lysis of leukocytes, serial dilution and pour plate counts (16).

Bactericidal effect of antibiotics on bacteria at $5^{\circ} \mathrm{C}$. Staphylococcus aureus $\left(1.0 \times 10^{5} / \mathrm{ml}\right)$ were incubated in nutrient broth at $37^{\circ} \mathrm{C}$ or at $5^{\circ} \mathrm{C}$ with either $10 \mu \mathrm{g} / \mathrm{ml}$ of penicillin or $10 \mu \mathrm{g} / \mathrm{ml}$ of rifampin. After $18 \mathrm{~h}$, serial dilution and pour plates were made to quantitate the number of viable colony-forming units.

$\left[{ }^{14} \mathrm{C}\right]$ penicillin binding to intraleukocytic and extraleukocytic bacteria. $2 \times 10^{8}$ leukocytes obtained from peripheral blood suspended in $10 \mathrm{ml}$ of HBSS with $10 \%$ autologous serum were incubated with Staphylococcus aureus (502A) at a ratio of 5 bacteria to 1 leukocyte. After tumbling the mixture at $12 \mathrm{rpm}$ for $30 \mathrm{~min}$ at $37^{\circ} \mathrm{C}, 0.1 \mathrm{ml}$ of the leukocyte-bacteria mixture was removed and viable staphylococci were quantitated by hypotonic lysis of the leukocytes, serial dilution, and pour plates. $26.8 \mathrm{pmol} / \mathrm{ml}(0.01 \mu \mathrm{g} / \mathrm{ml})$ of [benzyl ${ }^{14} \mathrm{C}$ ]penicillin $(121 \mu \mathrm{Ci} / \mathrm{mg})$ were added to the leukocyte-bacteria suspension and incubation with tumbling was continued for $2 \mathrm{~h}$. The mixture was then placed in a refrigerated ultracentrifuge (Spinco Model L; Spinco Div., Beckman Instruments, Palo Alto, Calif.) and centrifuged at $10,000 \mathrm{~g}$ for $30 \mathrm{~min}$. The supernatant fluid was saved and the sediment was washed twice with dextrose broth (Baltimore Biologic Laboratories). The sediments were resuspended in $0.2 \mathrm{ml} \mathrm{H} \mathrm{H}_{2} \mathrm{O}$ and mixed with $20 \mathrm{ml}$ scintillation counting fluid prepared by mixing $660 \mathrm{ml}$ of toluene, $300 \mathrm{ml}$ of methanol, and $40 \mathrm{ml}$ of Liquifluor (New England $\mathrm{Nu}$ clear Corp., Boston, Mass.). Counting efficiency was $75 \%$.

${ }^{1}$ Abbreviations used in this paper: HBSS, Hanks' balanced salt solution; PMN, polymorphonuclear neutrophil.
Supernatant scintillation counts were also performed on $0.2 \mathrm{ml}$ samples of the $10,000 \mathrm{~g}$ supernatant fluid. Corrections were made for quenching and appropriate blanks were subtracted. Studies were also performed with leukocytes alone to measure penicillin binding by these cells. Other experiments were done with sonically disrupted leukocytes and numbers of live bacteria equal to those surviving inside phagocytes.

Antibiotic distribution in leukocytes. A leukocyte suspension was prepared as previously described and the erythrocytes were hypotonically lysed $\times 2$ with water. The leukocytes were resuspended in $4.5 \mathrm{ml}$ of HBSS with bicarbonate and divided into five aliquots of $0.9 \mathrm{ml}$ containing $5 \times 10^{7}$ leukocytes each and placed in $2 \mathrm{ml} \frac{5}{16}$ in $\times 115$ in cellulose tubes. [Benzyl- ${ }^{14} \mathrm{C}$ ] penicillin potassium $(4 \mathrm{mCi} /$ $\mathrm{mmol}$ ) was obtained from Amersham/Searle Corp. (Arlington Heights, Ill.), $\mathrm{Na}_{2}{ }^{85} \mathrm{SO}_{4}(780 \mathrm{mCi} / \mathrm{mmol})$ and ${ }^{8} \mathrm{H}_{2} \mathrm{O}$ $(1 \mathrm{mCi} / \mathrm{g})$ were obtained from New England Nuclear Corp. Dr. Hans Heymann of Ciba-Geigy Corp. kindly supplied $\left[{ }^{14} \mathrm{C}\right]$ rifampin $(2.2 \mu \mathrm{Ci} / \mathrm{mg})$. The labeled penicillin was mixed with 12.9 parts cold penicillin so that equal molar concentrations of penicillin and rifampin had equal radioactivity $\left(2.28 \times 10^{-5} \mathrm{mmol}=0.05 \mu \mathrm{Ci}\right)$.

The isotopically labelled substance to be used was added to the tubes and tumbled end over end at $12 \mathrm{rpm}$ for $2 \mathrm{~h}$ at $37^{\circ} \mathrm{C}$. Just before tumbling and at the end of tumbling $0.1 \mathrm{ml}$ of the suspension was removed and placed in $10 \mathrm{ml}$ Bray's counting fluid and counted in a Beckman LS-250 liquid scintillation counter. The remainder of the suspension was centrifuged at $4,500 \mathrm{~g}$ in a Spinco Model L ultracentrifuge. The supernatant fluid was decanted and $0.1 \mathrm{ml}$ was counted as described above. The tube with the remaining leukocyte pellet was inverted and wiped to remove as much extracellular water as possible.

The entire pellet was then mixed in Bray's solution and placed in a scintillation counting vial and counted as above. There were no significant differences between ${ }^{3} \mathrm{H}$ counts done on predigested cell pellets as compared with counts done on pellets directly mixed in Bray's counting solution. The counting efficiency was $34 \%$ for ${ }^{3} \mathrm{H}$ and $75 \%$ for ${ }^{14} \mathrm{C}$ and ${ }^{35} \mathrm{~S}$. Calculations were as follows: total water space in the cell pellet $=$ corrected ${ }^{3} \mathrm{H}$ counts cell pellet $\div$ corrected ${ }^{3} \mathrm{H}$ counts $/ \mathrm{ml}$ of supernatant fluid. Extracellular water in the pellet $=$ corrected ${ }^{35} \mathrm{~S}$ counts cell pellet $\div$ corrected ${ }^{35} \mathrm{~S}$ counts $/ \mathrm{ml}$ of supernatant fluid. Antibiotic concentrations in the pellet $=$ corrected ${ }^{14} \mathrm{C}$ counts cell pellet $\div$ corrected ${ }^{14} \mathrm{C}$ counts/pmol of antibiotic.

Lipid diffusibility of antibiotics. In order to obtain an index of the diffusibility of antibiotics through lipid, filter paper discs soaked in aqueous solutions of antibiotics were placed in wells in agar containing cottonseed oil. Zones of inhibition of bacterial growth in agar were measured. Sarcina lutea (ATCC 9341) was suspended in saline to give $20 \%$ light transmission at $580 \mathrm{~nm}$ and $0.225 \mathrm{ml}$ of this suspension was mixed in $100 \mathrm{ml}$ of Difco Medium II agar at $45^{\circ} \mathrm{C} .10 \mathrm{ml}$ of the above mixture was poured into 100 $\mathrm{mm} \times 15 \mathrm{~mm}$ plastic petri dishes. After the agar hardened, $12 \mathrm{~mm}$ diameter wells were cut utilizing plastic test tubes. $\frac{1}{4}$ in diameter blank paper discs (Baltimore Biologic Laboratories) were soaked with varying concentrations of antibiotics diluted in HBSS. The wells were filled with either cottonseed oil or HBSS and the discs were carefully placed in the center. After $18 \mathrm{~h}$ of incubation the zone diameters of bacterial inhibition were read. A strain of Staphylococcus cpidermidis was utilized in the experiments with gentamicin. Streptomycin was tested with Difco Medium I (Difco Laboratories, Detroit, Mich.) and Bacillus subtilis. 


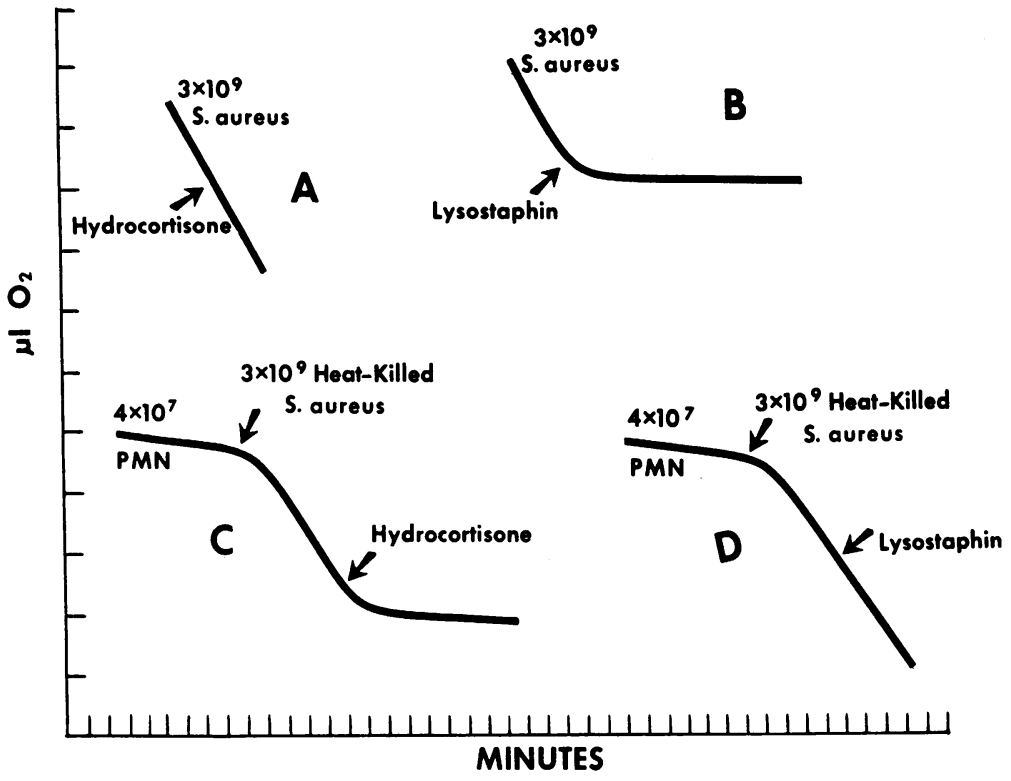

Figure 1 Oxygen consumption of bacteria and/or leukocytes measured in a polarographic oxygen monitor. The ordinate is marked in units of $1 \mu \mathrm{O}_{2}$ and the abscissa in units of 1 min. $(A)$ Hydrocortisone does not interfere with oxygen consumption of staphylococci. $(B)$ Lysostaphin abolished oxygen consumption of staphylococci. $(C)$ Hydrocortisone eliminates oxygen consumption of phagocytizing leukocytes. $(D)$ Lysostaphin does not affect oxygen consumption of phagocytizing leukocytes.

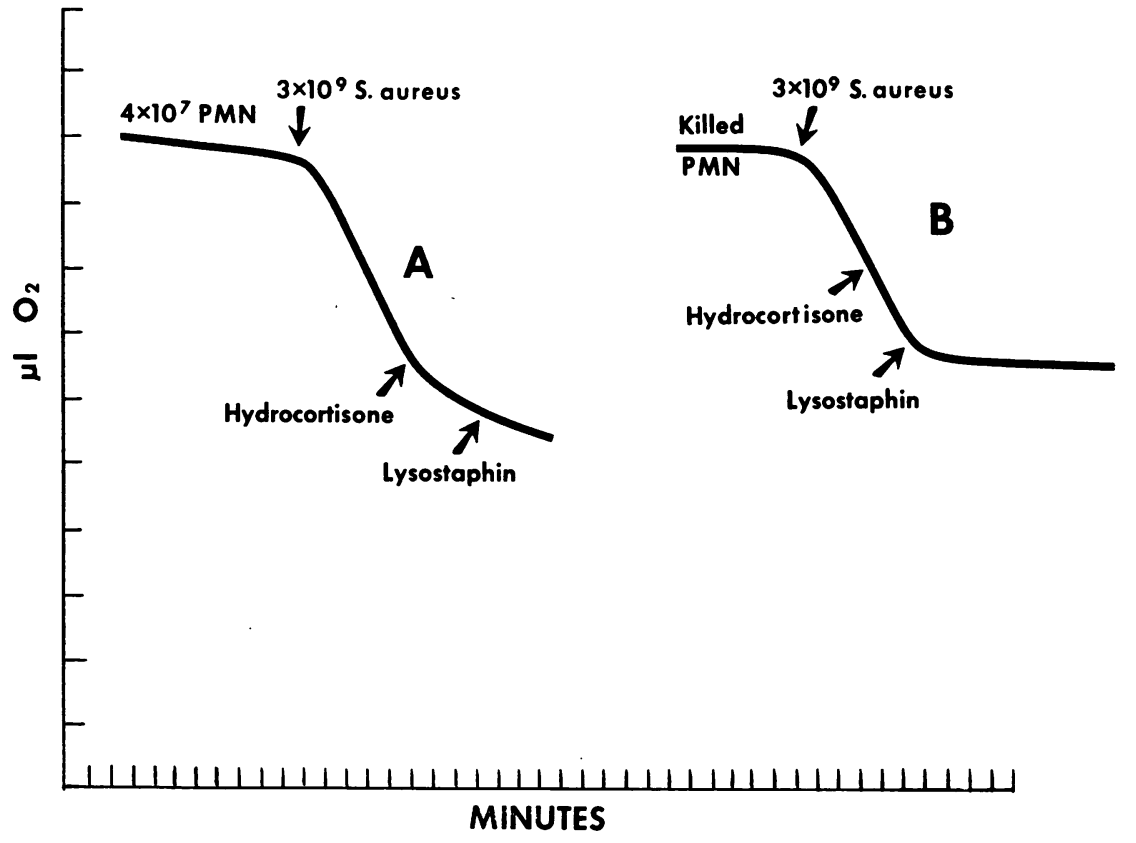

Figure 2 Oxygen consumption of bacteria and/or leukocytes measured in a polarographic oxygen monitor. $(A)$ Oxygen consumption of intraleukocytic bacteria continues after addition of hydrocortisone and lysostaphin. $(B)$ Oxygen consumption of bacteria plus killed leukocytes is abolished by addition of lysostaphin. 


\section{RESULTS}

Oxygen consumption. Results are shown in Figs. 1 and 2. Live intracellular $S$. aureus continued to consume oxygen after the addition of lysostaphin (which abolishes extraleukocytic bacterial oxygen consumption) and hydrocortisone (which stops post phagocytic leukocyte oxygen consumption). In contrast to this the oxygen consumption of $S$. aureus incubated with heat-killed leukocytes was completely abolished by lysostaphin. The mean oxygen consumption ( \pm SEM) with live leukocytes was $1.50 \pm 0.31(n=5) \mu \mathrm{l} / \mathrm{min}$ and for the group with heat-killed leukocytes was $0.30 \pm 0.17(n=5) \mu \mathrm{l} /$ $\min (P<0.02)$.

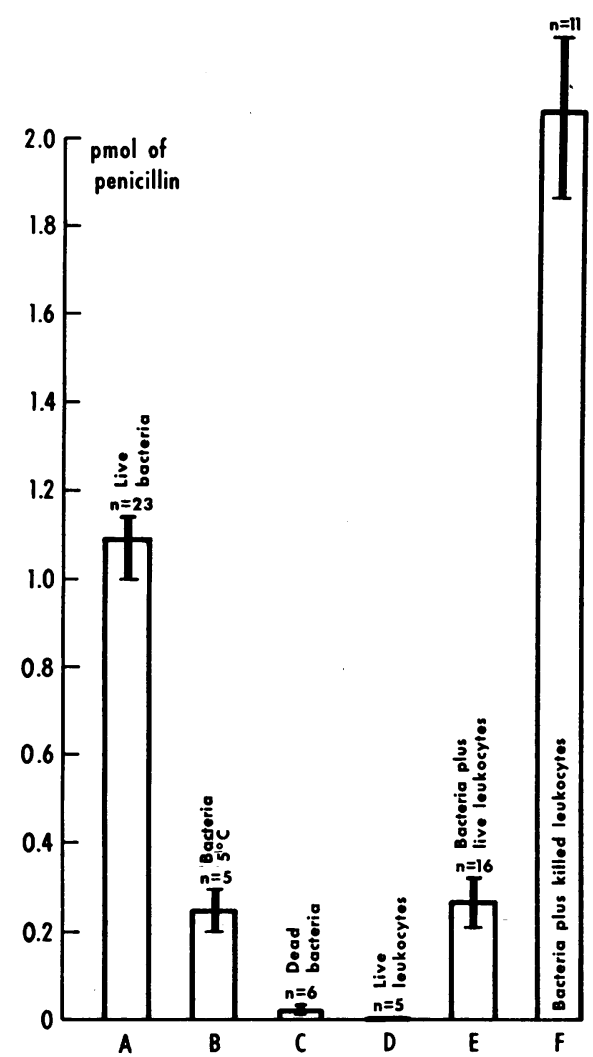

FIGURE 3 The bars represent picomoles ( \pm SEM) of $\left[{ }^{14} \mathrm{C}\right]-$ penicillin bound to the twice-washed sediment. $(A, B)$ Incubation of $\left[{ }^{14} \mathrm{C}\right]$ penicillin with $1.0 \times 10^{9}$ live staphylococci at $37^{\circ} \mathrm{C}$ and at $5^{\circ} \mathrm{C}$, respectively, for $2 \mathrm{~h}$. (C) Incubation of $\left[{ }^{14} \mathrm{C}\right]$ penicillin with $1.0 \times 10^{\circ}$ heat-killed staphylococci for $2 \mathrm{~h}$. (D) Incubation of $\left[{ }^{14} \mathrm{C}\right]$ penicillin with $2.0 \times 10^{8}$ human leukocytes $(80 \% \mathrm{PMN})$ for $2 \mathrm{~h}$. (E) Prior incubation of $2.0 \times 10^{8}$ leukocytes with $2.0 \times 10^{9}$ staphylococci for $30 \mathrm{~min}$ (at this time $99 \%$ of the bacteria are ingested and there are $1.0 \times 10^{9}$ surviving staphylococci). $\left[{ }^{14} \mathrm{C}\right]$ penicillin is then added and the mixture incubated for $2 \mathrm{~h}$. (F) $1.0 \times 10^{8}$ staphylococci and $2.0 \times 10^{8}$ sonically disrupted leukocytes were incubated for $2 \mathrm{~h}$ with $\left[{ }^{14} \mathrm{C}\right]$ penicillin. $A$ vs. $B, A$ vs. $C, A$ vs. $E$, and $E$ vs. $F$ were all significantly different $(P<0.001$, Student's $t$ test $)$.
Bactericidal effect of antibiotics on bacteria at $5^{\circ} \mathrm{C}$. Both penicillin and rifampin sterilized the bacterial inoculum after incubation at $37^{\circ} \mathrm{C}$. Despite antibiotic concentrations well above the minimum bactericidal concentrations $(0.195 \mu \mathrm{g} / \mathrm{ml}$ for rifampin and $0.059 \mu \mathrm{g} / \mathrm{ml}$ for penicillin) neither antibiotic killed bacteria incubated at $5^{\circ} \mathrm{C} ; 8.9 \times 10^{4}$ staphylococci survived incubation with $10 \mu \mathrm{g} / \mathrm{ml}$ of penicillin and $7.5 \times 10^{4}$ staphylococci survived incubation with $10 \mu \mathrm{g} / \mathrm{ml}$ of rifampin.

$\left[{ }^{1 "} \mathrm{C}\right]$ penicillin binding to intraleukocytic and extralenkocytic bacteria. The results are shown in Fig. 3. Live $S$. aureus at $37^{\circ} \mathrm{C}$ bound 4.4 times as much penicillin as $S$. aureus at $5^{\circ} \mathrm{C}$ and 55 times as much penicillin as dead $S$. aureus. Penicillin did not bind at all to live or killed leukocytes. Live leukocytes that ingested heatkilled bacteria also did not bind penicillin. The enhanced penicillin binding to bacteria incubated with sonicated cells is unexplained. It may represent increased bacterial growth in the presence of factors from the disrupted leukocytes. Bacteria incubated with killed leukocytes bound seven times as much penicillin as did equal numbers of bacteria surviving within living leukocytes.

Antibiotic distribution in leukocytes. Fig. 4 shows the intracellular and extracellular water spaces in the leukocyte pellets. $73 \%$ of the total water in the pellet

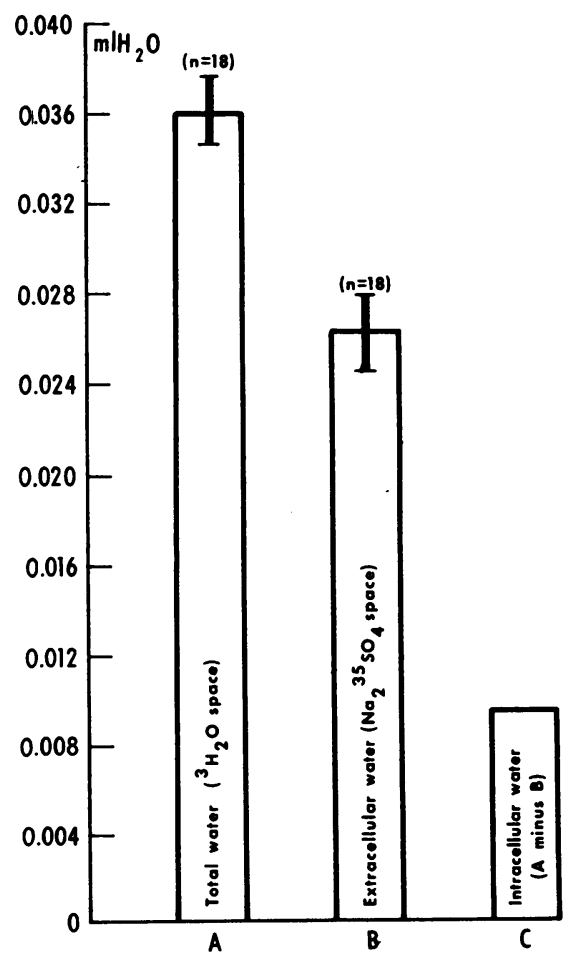

Figure $4{ }^{3} \mathrm{H}_{2} \mathrm{O}$ or $\mathrm{Na}_{2}{ }^{35} \mathrm{SO}_{4}$ was incubated with $5.0 \times 10^{7}$ human leukocytes $(80 \%$ PMN). The bars represent water spaces $( \pm S E M)$ in the unwashed $4,500 \mathrm{~g}$ pellet. The differences are significant $(P<0.001$, Student's $t$ test $)$. 
Penicillin Rifampin

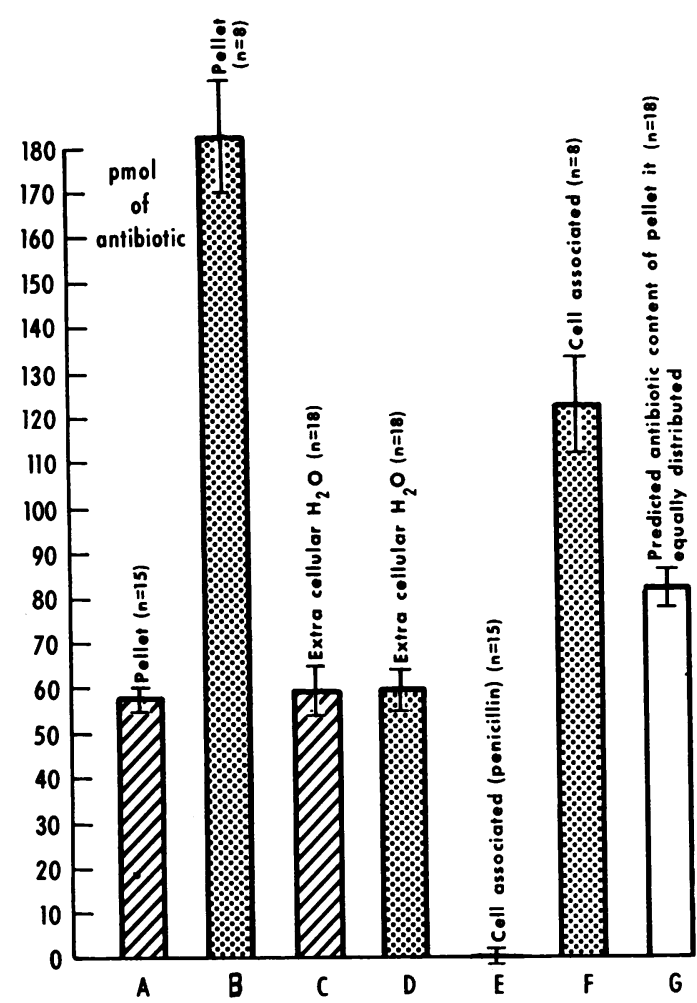

FIGURE $55.0 \times 10^{7}$ human leukocytes $(80 \%$ PMN) were incubated with $2,280 \mathrm{pmol} / \mathrm{ml}$ of ${ }^{14} \mathrm{C}$-labeled rifampin or penicillin for $2 \mathrm{~h}$. The bars represent picomoles ( \pm SEM) of antibiotic present in the 4,500 $\mathrm{g}$ unwashed leukocyte pellet. Values for extracellular water and total pellet water were obtained from Fig. 4. $A$ shows the penicillin content in the pellet. $B$ shows the rifampin content in the pellet. $C$ shows the penicillin present in the extracellular water space of the pellet. $D$ shows the rifampin present in the extracellular water space of the pellet. $E$ is the cell-associated penicillin (total pellet penicillin - extracellular water penicillin). $F$ is the cell-associated rifampin (total pellet rifampin - extracellular water rifampin). $G$ shows the predicted antibiotic content of the pellet for an antibiotic that is freely diffusible between extracellular water and intracellular water. All the penicillin in the pellet could be accounted for in the extracellular water. $A$ and $C$ were not significantly different $(0.6>P>0.7)$, while $A$ vs. $B$ and $E$ vs. $F$ were significantly different $(P<0.001$, Student's $t$ test).

is extracellular. This figure is compatible with the data of Baron and Ahmed (12) and Patrick and Hilton (13) who used a special technique for preparing pellets as free as possible from extracellular water. They found their leukocyte pellets to contain $67 \%$ of the total pellet water as extracellular water.

Fig. 5 shows the amount of antibiotic present in various components of the cell pellet. The entire penicillin content of the pellet could be accounted for in the extra-
TABLE I

Lipid Diffusibility of Antibiotics

\begin{tabular}{lcc}
\hline \multicolumn{1}{c}{ Antibiotic } & $\begin{array}{c}\text { Zone of } \\
\text { inhibition } \\
\text { in Hanks } \\
\text { solution }\end{array}$ & $\begin{array}{c}\text { Zone of } \\
\text { inhibition } \\
\text { in cotton- } \\
\text { seed oil }\end{array}$ \\
\hline Rifampin & $c m$ & $c m$ \\
Penicillin & 4.2 & 3.2 \\
Methicillin & 5.4 & 0 \\
Cephalothin & 4.3 & 0 \\
Gentamicin & 4.1 & 0 \\
Vancomycin & 2.0 & 0 \\
Tetracycline & 2.5 & 0 \\
Streptomycin & 2.7 & 0 \\
Chloramphenicol & 2.9 & 0 \\
Lincomycin & 3.0 & 0 \\
Clindamycin & 3.8 & 0 \\
Erythromycin (base) & 4.8 & 0 \\
Erythromycin estolate & 3.6 & 0 \\
Erythromycin lactobionate & 3.8 & 0 \\
Oleandomycin & 3.6 & 0 \\
Nalidixic acid & 3.0 & 0 \\
Bacitracin 100 U & 3.0 & 0 \\
Nitrofurantoin 30 $\mu \mathrm{g}$ & 3.7 & 0 \\
& 3.3 & 0 \\
\hline
\end{tabular}

Blank filter paper discs were soaked in $100 \mu \mathrm{g} / \mathrm{ml}$ of antibiotic except as noted and placed in wells cut in seeded agar culture dishes filled with either Hanks' balanced salt solution or with cottonseed oil. After $24 \mathrm{~h}$ of incubation zones of inhibition around the wells were measured.

cellular water. In contrast, rifampin was concentrated in the cells when compared with the extracellular water.

Lipid diffusibility of antibiotics. Table I shows the results of studies done with 18 antibiotics. Only rifampin diffused through cottonseed oil to give a zone of inhibition. Rifampin was also the only one of these 18 antibiotics that was capable of killing intracellular bacteria (6) (Mandell, G. L., unpublished observations).

\section{DISCUSSION}

In 1916 Rous and Jones described the inability of bactericidal substances to kill pathogenic microorganisms inside living tissue cells (17). More recently it has been well-documented that living intracellular bacteria are protected against the lethal action of antibiotics (1-6). The mechanism whereby this occurs has been a subject of much discussion and investigation. Dr. Harry Eagle, in a series of papers in the 1950's (8-10) studied penicillin binding by bacteria and mammalian cells. He showed that penicillin was bound and concentrated by penicillinsensitive bacteria. His studies were interpreted to show that penicillin could penetrate mouse fibroblasts and $\mathrm{HeLa}$ cells so that concentrations of intracellular penicillin were about $63 \%$ of that in the surrounding media. 
Because of these findings, Eagle assumed that protection of ingested bacteria from antibiotics was not due to impermeability of the cell membranes to these antibiotics, but was perhaps due to altered bacterial metabolism. However, no correction was made for extracellular fluid contamination of the cell pellet which could have explained the "cell-associated" penicillin values.

Werner, Knight, and McDermott (18) showed that antibiotics were able to penetrate into "artificial abscesses" implanted into mice, thus reinforcing the idea that antibiotics did penetrate to the site where they were needed, but once there, were for some reason ineffective.

Hopps, Jackson, Danauskas, and Smadel (19) found that chloramphenicol eliminated Rickettsia that had infected cultured mouse fibroblasts. This was a fairly slow process and $41 \%$ of the cells still had organisms after 7 days of antibiotic treatment. In subsequent studies, Showacre, Hopps, du Buy, and Smadel (20) and Hopps, Smadel, Bernheim, Danauskas, and Jackson (21) demonstrated that Salmonella typhosa ingested by mouse fibroblasts rapidly stopped multiplying after exposure to penicillin, streptomycin, chloramphenicol, kanamycin, chlortetracycline, or synnematin (cephalosporin $\mathrm{P}$ ). However, they found very little change in the number of viable organisms up to $24 \mathrm{~h}$ and it took more than 10 days to "cure" cultures. Our prior studies concerning the effect of antibiotics on Escherichia coli ingested by macrophages showed that ampicillin and gentamicin did not kill all intracellular $E$. coli. In contrast, rifampin did kill all intracellular bacteria after $18 \mathrm{~h}$ of incubation (22). Bonventre, Hayes, and Imhoff (23) found that cutured mouse peritoneal macrophages were relatively impermeable to tritiated streptomycin for a period up to $20 \mathrm{~h}$. Subsequent studies by Bonventre and Imhoff (24) showed that these cells could concentrate significant amounts of tritiated dihydrostreptomycin provided that the incubation period was sufficiently extended.

There are several possible ways to resolve our findings and those of Hopps and Showacre. First, the cells that they used were not primarily phagocytic cells and thus, they may behave differently. Second, the process of infection in these nonbactericidal cells may have damaged these cells so as to render them more permeable to antibiotics. Third, long periods of incubation probably do, at least in fibroblasts and macrophages, result in the entrance of antibiotic into cells and this may be, in part, due to pinocytosis. Polymorphonuclear neutrophils which are short-lived would not have the opportunity to take in antibiotics over a period of days to weeks.

The present studies support the hypothesis that the inability of penicillin to kill bacteria that are inside phagocytes is due to a lack of penetration of the phagocyte by the antibiotic. Since the oxygen consumption of ingested bacteria continues, this indicates that these mi- crobes are actively metabolizing although the degree of metabolic activity could not be quantitated. Radiolabeled penicillin is actively bound by bacteria but this binding is markedly diminished when radiolabeled penicillin is incubated with bacteria that are inside cells. The small amount of penicillin bound to "intracellular" bacteria could reflect cells that were damaged or dead and thus allowed the entrance of the antibiotic.

Incubation of labeled penicillin or rifampin with leukocyte suspensions was done to measure penetration of the antibiotics into the cells. The total water content of the leukocyte pellet was quantitated with tritiated water and the extracellular water content was measured utilizing $\mathrm{Na}^{2}{ }^{35} \mathrm{SO}_{4}$ which has been shown to be a valid measurement of extracellular water in leukocyte suspensions $(12,13)$. The penicillin content of the cell pellet could all be accounted for in the extracellular water. In fact, penicillin was an accurate measure of extracellular water when compared with $\mathrm{Na}_{2} \mathrm{SO}_{4}$. In marked contrast to penicillin, 2.2 times as much rifampin was found in the cell pellet as could be explained by rifampin in the extracellular fluid. Rifampin, which is a "zwitterion" (25), was also the only antibiotic (of 18 tested) that was able to penetrate leukocytes and kill ingested organisms. These same 18 antimicrobial compounds were studied to determine ability to diffuse through cottonseed oil and only rifampin could do this. The observation that neither penicillin nor rifampin could kill staphylococci at $5^{\circ} \mathrm{C}$ suggests that the ability of only rifampsin to kill intracellular organisms is not due to a unique mechanism of action.

Penicillin cannot penetrate leukocytes and cannot kill intraleukocytic bacteria. Most other antibiotics probably are ineffective in killing intracellular organisms for the same reason. The unique ability of rifampin to penetrate phagocytes is the probable explanation for its ability to kill bacteria inside polymorphonuclear neutrophils (6) or inside macrophages (22).

\section{ACKNOWLEDGMENTS}

We would like to thank Miss Linda Johnston, Mrs. Athanasia Economou, and Mrs. Theckla Sterrett for skillful technical assistance.

This work was supported by Research Grant AI-09504 from the National Institutes of Health.

\section{REFERENCES}

1. Magoffin, R. L., and W. W. Spink. 1951. The protection of intracellular brucella against streptomycin alone and in combination with other antibiotics. J. Lab. Clin. Med. $37: 924$.

2. Shaffer, J. M., C. J. Kucera, and W. W. Spink. 1953. The protection of intracellular brucella against therapeutic agents and the bactericidal action of serum. $J$. Exp. Med. $97: 77$.

3. Holmes, B., P. G. Quie, D. B. Windhorst, B. Pollara, and R. A. Good. 1966. Protection of phagocytized bac-

\section{G. L. Mandell}


teria from the killing action of antibiotics. Nature (Lond.). 210: 1131.

4. Alexander, J. W., and R. A. Good. 1968. Effect of antibiotics on the bactericidal activity of human leukocytes. J. Lab. Clin. Med. 71: 971 .

5. Solberg, C. O. 1972. Protection of phagocytized bacteria against antibiotics. A new method for the evaluation of neutrophil granulocyte functions. Acta Med. Scand. $191: 383$.

6. Mandell, G. L., and T. K. Vest. 1972. Killing of intraleukocytic Staphylococcus aureus by rifampin: in vitro and in vivo studies. J. Infect. Dis. 125: 486.

7. Chain, E., and E. S. Duthie. 1945. Bactericidal and bacteriolytic action of penicillin on the staphylococcus. Lancet. 1: 652.

8. Eagle, H. 1954. The binding of penicillin in relation to its cytotoxic action. III. The binding of penicillin by mammalian cells in tissue culture ( $\mathrm{HeLa}$ and $\mathrm{L}$ strains). J. Exp. Med. 100: 117.

9. Eagle, H. 1954. The binding of penicillin in relation to its cytotoxic action. I. Correlation between the penicillin sensitivity and combining activity of intact bacteria and cell-free extracts. J. Exp. Med. 99: 207.

10. Eagle, H. 1954. The binding of penicillin in relation to its cytotoxic action. II. The reactivity with penicillin of resistant variants of streptococci, pneumococci, and staphylococci. J. Exp. Med. 100: 103.

11. Pace, N., L. Kline, H. K. Schachman, and M. Harfenist. 1947. Studies on body composition. IV. Use of radioactive hydrogen for measurement in vivo of total body water. J. Biol. Chem. 168: 459.

12. Baron, D. N., and S. A. Ahmed. 1969. Intracellular concentrations of water and of the principal electrolytes determined by analysis of isolated human leukocytes. Clin. Sci. 37: 205.

13. Patrick, J., and P. J. Hilton. 1972. The measurement of the extracellular space in an in vitro system of human leucocytes. Clin. Sci. 42: 647.

14. Malawista, S. E., and P. T. Bodel. 1967. The dissociation by colchicine of phagocytosis from increased oxygen consumption in human leukocytes. J. Clin. Invest. 46: 786.

15. Mandell, G. L., W. Rubin, and E. W. Hook. 1970. The effect of an NADH oxidase inhibitor (hydrocortisone) on polymorphonuclear leukocyte bactericidal activity. J. Clin. Invest. 49: 1381.

16. Tan, J. S., C. Watanakunakorn, and J. P. Phair. 1971. A modified assay of neutrophil function: Use of lysostaphin to differentiate defective phagocytosis from impaired intracellular killing. J. Lab. Clin. Med. 78: 316.

17. Rous, P., and F. S. Jones. 1916. The protection of pathogenic microorganisms by living tissue cells. $J$. Exp. Med. 23: 601 .

18. Werner, C. A., V. Knight, and W. McDermott. 1954 Studies of microbial populations artificially localized in vivo. I. Multiplication of bacteria and distribution of drugs in agar loci. J. Clin. Invest. 33: 742.

19. Hopps, H. E., E. B. Jackson, J. X. Danauskas, and J. E. Smadel. 1959. Study on the growth of Rickettsiae. IV. Effect of chloramphenicol and several metabolic inhibitors on the multiplication of Rickettsia tsutsugamushi in tissue culture cells. J. Immunol. 82: 172.

20. Showacre, J. L., H. E. Hopps, H. G. du Buy, and J. E. Smadel. 1961. Effect of antibiotics on intracellular Salmonella typhosa. I. Demonstration by phase microscopy of prompt inhibition of intracellular multiplication. J. Immunol. 87: 153 .

21. Hopps, H. E., J. E. Smadel, B. C. Bernheim, J. X. Danauskas, and E. B. Jackson. 1961. Effect of antibiotics on intracellular Salmonella typhosa. II. Elimination of infection by prolonged treatment. J. Immunol. $87: 162$.

22. Lobo, M. C., and G. L. Mandell. 1973. The effect of antibiotics on Escherichia coli ingested by macrophages. Proc. Soc. Exp. Biol. Med. 142: 1048.

23. Bonventre, P. F., R. Hayes, and J. Imhoff. 1967. Autoradiographic evidence for the impermeability of mouse peritoneal macrophages to tritiated streptomycin. J. Bacteriol. 93: 445.

24. Bonventre, P. F., and J. G. Imhoff. 1970. Uptake of ${ }^{3} \mathrm{H}$-dihydrostreptomycin by macrophages in culture. Infect. Immun. 2: 89.

25. Maggi, N., C. R. Pasqualucci, R. Ballotta, and P. Sensi. 1966. Rifampicin: a new orally active rifamycin. Chemotherapia. 11: 285. 